Iryna Kotsiuba ${ }^{1}, \mathrm{PhD}$, Associate professor, Department of Ecology ORCID: 0000-0001-8964-3560 e-mail: chaszmin30@gmail.com

Sergii Lyko², PhD, Associate professor, Department of Ecology ORCID: 0000-0001-8964-3560 e-mail: chaszmin30@gmail.com

Vitalina Lukianova ${ }^{3}, \mathrm{PhD}$, Associate professor, Department of Ecology and Safety of Vital Functions

ORCID: 0000-0001-8964-3560 e-mail: vitalina_lk@i.ua

Yevheniia Anpilova ${ }^{4}, \mathrm{PhD}$, Senior Research Scientist, Department of Natural Resources ORCID: 0000-0002-4107-0617 e-mail: anpilova@ukr.net

${ }^{1}$ Zhytomyr State Technological University, Zhytomyr, Ukraine

${ }^{2}$ Rivne State Humanitarian University, Rivne, Ukraine

${ }^{3}$ National Transport University, Kyiv, Ukraine

${ }^{4}$ Institute of Telecommunications and Global Information Space of the National Academy of Sciences of Ukraine, Kyiv, Ukraine

\title{
SCIENTIFIC AND THEORETICAL JUSTIFICATION OF SOLID HOUSEHOLD WASTE ACCUMULATION IN ZHYTOMYR REGION
}

\begin{abstract}
Practical experience of solid domestic waste (MSW) management in Ukraine and developed countries is analyzed. Theoretical volumes of MSW accumulation taking into account statistical factors are studied. The generalized method of MSW accumulation volumes allows forecasting their formation from the factors and evaluating the morphological composition of MSW in the region. The system for optimizing community waste management at the collection and disposal stage with the quality of the optimality criterion has been proposed. The degree of recycling and the costs of collecting and transporting waste should be taken as a criterion for optimising the urban waste management system at the collection and disposal stage. The quality analysis of the waste management system in the Zhytomyr region made it possible to identify the main problems in municipal waste management and the main reasons for their occurrence. The survey shows that the main problem in the area of waste management is the low efficiency of the existing management system, accompanied by the introduction of outdated and inefficient management methods with the lack of effective interaction of all participants in the waste management process and, above all, the lack of public involvement in solving the problem. The authors concluded that at the present time Zhytomyr city and Zhytomyr Region faced the following problems in the area of solid waste management: the number of spontaneous landfills has increased; the number of modern waste collection bins is insufficient and there are no bins for separate waste collection; the quality of solid waste collection services is inadequate; there is no recycling plant in Zhytomyr; large amount of household waste in the city landfill and absence of monitoring of its impact on the environment.
\end{abstract}

Keywords: waste morphology; volume of solid municipal waste; MSW accumulation; dump; landfill

(ㄷ І.Г. Коцюба, С.М. Лико, В.В. Лук’янова, Є.С. Анпілова, 2020 


\title{
І.Г. Коцюба ${ }^{1}$, С.М. Лико ${ }^{2}$, В.В. Лук'янова ${ }^{3}$, Є.С. Анпілова ${ }^{4}$
}

${ }^{1}$ Житомирський державний технологічний університет, м. Житомир, Україна

${ }^{2}$ Рівненський державний гуманітарний університет, м. Рівне, Україна

${ }^{3}$ Національний транспортний університет, м. Київ, Україна

${ }^{4}$ Інститут телекомунікацій і глобального інформаційного простору НАН України, м. Київ, Україна

\section{НАУКОВО-ТЕОРЕТИЧНЕ ОБГРУНТУВАННЯ НАКОПИЧЕННЯ ТВЕРДИХ ПОБУТОВИХ ВІДХОДІВ ЖИТОМИРЩИНИ}

\begin{abstract}
Анотація. Проаналізований практичний досвід поводження з твердими побутовими відходами (ТПВ) в Україні та розвинених країнах світу. Вивчено теоретичні обсяги накопичення ТПВ з урахуванням статистичних чинників. Запропонована система оптимізації щодо управління відходами громад на стадії ї збору $i$ видалення за допомогою якості критерію оптимальності. При вирішенні питань оптимізачії системи управління міськими відходами на стадії їх збору і видалення в якості критерію оптимальності слід приймати ступінь утилізаиії відходів (кількість відходів для вторинного використання на основі їх роздільного збору в житловому $і$ нежилому секторі міста та сортування відходів, збагачених корисними компонентами), витрати на збір і транспортування відходів. Узагальнена методика обсягів накопичення ТПВ дозволяє прогнозувати їх утворення з чинників та оцінений морфологічний склад ТПВ області. Якісний аналіз системи управління поводженням 3 відходами Житомирської області дозволив визначити основні проблеми у сфері поводження з комунальними відходами та виявити основні причини їх появи. Аналіз, виконаний авторами, показує, що основною проблемою у сфері поводження з відходами є низька ефективність існуючої системи управління, що супроводжується впровадженням застарілих та низькоефективних методів управління з відсутністю ефективної взаємодї всіх учасників прочесу поводження з відходами і насамперед відсутність залучення громади для вирішення проблеми. Автори дійшли висновку, що наразі в Житомирі та Житомирській області, у сфері управління та поводження з твердими побутовими відходами наявні наступні проблеми, а саме: збільшилась кількість стихійних сміттєзвалищ; наявна недостатня кількість сучасних контейнерів для збору побутових відходів та відсутні контейнери для роздільного збирання відходів; спостерігається неналежна якість надання послуг з вивезення твердих побутових відходів; відсутній сміттєпереробний завод; виявлено велику кількість побутових відходів на території міського звалища та відсутній моніторинг впливу ТВП на довкілля.
\end{abstract}

Ключові слова: морфологія відходів; обсяг твердих комунальних відходів; накопичення ТПВ; звалище; полігон

\section{Постановка проблеми}

Основним завданням комплексного вирішення практичних питань управління потоком відходів в місті є організація раціонального поводження з відходами [1], що відповідає сучасним еколого-економічним та ресурсним вимогам i включає мінімізацію витрат на санітарну очистку міста, використання відходів як джерела сировини, забезпечення екологічної безпеки, перехід від полігонного захоронення відходів до їх промислової переробки [2]. Тому, комплексне управління відходами включає в себе організацію збору, видалення 
(транспортування), сортування, переробки та захоронення, а також зведення до мінімуму кількості відходів, які направляються на захоронення [1-9].

Першочерговим завданням в розробці схеми управління відходами $€$ організація їх збору, видалення та використання сучасних підходів із залученням методів Д33 та ГІС [10-12, 23]. Зволікання з видаленням відходів 3 місць їх утворення неприпустимо, бо може призвести до серйозного забруднення міст. Видаляють відходи або на полігони захоронення, або на спеціальні об'єкти для переробки та знешкодження. Поступовий перехід від полігонного захоронення до промислової переробки є основною тенденцією вирішення проблеми відходів у світовій практиці [13]. Промислова переробка відходів знімає протиріччя між містом, де утворюється велика кількість відходів, і передмістям, де відходи повинні бути розміщені. Мінімізація кількості відходів, що направляються в місця їх переробки і захоронення, вирішується на основі включення в схему управління операцій сортування відходів і виділення ресурсів, придатних для подальшого використання $[1,6,14,15]$.

Таким чином, на стадії збору відходів багато в чому визначається ефективність і безпека їх подальшої переробки та захоронення. При вирішенні питань оптимізації системи управління міськими відходами на стадії їх збору і видалення в якості критерію оптимальності слід приймати ступінь утилізації відходів (кількість відходів для вторинного використання на основі їх роздільного збору в житловому і нежилому секторі міста та сортування відходів, збагачених корисними компонентами), витрати на збір i транспортування відходів.

\section{Аналіз досліджень та публікацій}

Проведення порівняльного аналізу використання різновидів систем поводження 3 ТПВ у світовій практиці показало, що на сьогодні в світі основним напрямком поводження з відходами $\epsilon$ перехід від поховання (на полігонах і звалищах) до промислової переробки. Вчені світу посилюють пошуки можливостей використання відходів і їх окремих компонентів в якості вторинних ресурсів, що одночасно сприяє економії сировини і постійній турботі про охорону природи [14-19].

Кінцевою операцією в загальній схемі поводження 3 відходами в розвинених країнах $є$ промислова переробка [17], що вирішує питання знешкодження, утилізації та ліквідації невикористаного залишку відходів. Перехід від полігонного захоронення відходів до їх промислової переробки в Україні має стати довгостроковою стратегією кардинального вирішення проблеми відходів та, з огляду на дефіцит енергоносіїв, повинен вирішитися в першу чергу [20-22].

Необхідність послідовного впровадження в життя концепції сталого розвитку потребує розробки високоефективного обладнання та процесів утилізації ТПВ, що не лише забезпечить заощадження матеріальних та енергетичних ресурсів, але i зменшить забруднення навколишнього середовища. Найбільшою мірою сучасним вимогам відповідає побудова промислової технології за принципом комбінації різних методів переробки ТПВ (комплексна переробка ТПВ), створення і використання мобільних установок з ліквідації несанкціонованих і закритих звалищ. У зв'язку з цим 
одним $з$ пріоритетних напрямів наукових досліджень в екологічній безпеці $\epsilon$ розробка, вдосконалення та обгрунтований вибір ефективних шляхів переробки ТПВ.

Тому, основним етапом дослідження було теоретичне обгрунтування утворення твердих побутових відходів на Житомирщині.

\section{Матеріал і основні результати та їх аналіз}

Дослідження проводилися на звалищах об'єднаних територіальних громад Житомирщини. Всі побутові відходи мешканців Житомирщини без попереднього сортування складуються на звалищах, що стали джерелом інтенсивного забруднення атмосфери, підземних вод (а загалом загрозою епідемічного стану), що зумовлює необхідність удосконалення процесу складування відходів.

Переважна більшість житлових будинків Житомира $є$ висотними, оснащеними сміттєпроводами. Але в інших районних центрах області (Малин, Коростень, Бердичів) ситуація протилежна. Більшість будівель належить до приватного сектору. За наявності сміттєпроводу всі ТКВ, що накопичуються, надходять у сміттєпровід через приймальні вікна з клапанами, які розміщені на міжповерхових майданчиках. Відходи падають у сміттєприймальну камеру i подаються двірником у сміттєзбірний контейнер. За відсутності сміттєпроводу мешканці, двірники, прибиральники тощо виносять ТКВ до сміттєзбірних контейнерів, частина 3 яких встановлена групами на контейнерних майданчиках, інші по одному. Санітарний стан сміттєпроводів будинків є вкрай незадовільним. Незадовільним є також санітарний стан контейнерів, оскільки в місті не існує системи регулярного їх миття та дезінфекції.

На даний час в Житомирській області практикуються різні технології збирання та вивезення побутових відходів (табл. 1).

Таблиця 1 - Технології збирання та вивезення побутових відходів

\begin{tabular}{|c|c|c|}
\hline Об'єкт & 3бір & Вивіз ТКВ \\
\hline $\begin{array}{l}\text { Житловий сектор } \\
\text { багатоквартирної } \\
\text { забудови }\end{array}$ & $\begin{array}{l}\text { Стандартні } \\
\text { незмінювані } \\
\text { контейнери } \\
\text { місткістю } 0,75 \text { чи } \\
1,1 \text { м }^{3}\end{array}$ & $\begin{array}{llr}\text { Збиральні } & \text { сміттєвози за планово- } \\
\text { подвірною } & \text { системою } \\
\text { встановленими } & \text { маршрутами } \\
\text { графіками, } & \text { що } \\
\text { перевізниками } & \text { та позроблені } \\
\text { замовниками послугені із } \\
\text { відходів }\end{array}$ \\
\hline $\begin{array}{l}\text { Утворювачі відходів, } \\
\text { об'єкти невиробничої } \\
\text { сфери }\end{array}$ & $\begin{array}{l}\text { Контейнери } \\
\text { місткістю } 0,75 \text { чи } \\
1,1 \mathrm{~m}^{3}\end{array}$ & $\begin{array}{l}\text { Планово-регулярна система або } \\
\text { заявочна система (за дзвінком при } \\
\text { заповненні контейнера) } \\
\end{array}$ \\
\hline \multirow[t]{2}{*}{$\begin{array}{l}\text { Індивідуальна } \\
\text { забудова } \\
\text { (приватний сектор) }\end{array}$} & $\begin{array}{l}\text { Контейнери } \\
\text { місткістю } 0,75 \text { чи } \\
1,1 \mathrm{~m}^{3}\end{array}$ & $\begin{array}{l}\text { Збиральні сміттевози за планово- } \\
\text { регулярною (подвірною) системою } \\
\text { за встановленими маршрутами i } \\
\text { графіками }\end{array}$ \\
\hline & $\begin{array}{l}\text { Без використання } \\
\text { контейнерів }\end{array}$ & $\begin{array}{l}\text { Сміттєвоз рухається за встановленим } \\
\text { маршрутом і графіком, а мешканці } \\
\text { виносять ТПВ в полімерних пакетах } \\
\text { (чи іншій тарі) і завантажують їх у } \\
\text { сміттєвоз }\end{array}$ \\
\hline
\end{tabular}


У м. Житомирі існує розгалужена система заготівельних пунктів вторинної сировини. Основні види вторинної сировини, в тому числі відібраної із ТКВ: макулатура (картон, папір), скло (склотара, склобій), ПТЕФ пляшки, деякі види полімерної плівки, метали (чорні та кольорові), текстиль приймаються на різноманітних пунктах без обмежень обсягів.

Вивіз ТПВ здійснюється на полігони та звалища Житомирської області. На сьогодні в області діє 819 місць видалення відходів. Також слід відзначити, що більшість полігонів ТКВ не відповідають санітарним вимогам з експлуатації полігонів, а значна кількість полігонів вже вичерпала свій ресурс і стала фактором антропогенного навантаження на довкілля.

В області діє 6 полігонів, які, за даними Державної екологічної інспекції, не відповідають екологічним та природоохоронним вимогам - ТОВ «Міськкомунсервіс» Новоград-Волинський, Комунальне виробничогосподарське підприємство в м. Коростень, Малинське МКП «Благоустрій», Радомишльське міське комунальне п-во, ТОВ "Полісся-Екосфера", КП «АТП 0628».

Тверді побутові нетоксичні відходи IV класу небезпеки розміщуються також на міському сміттєзвалищі, яке розташоване біля с. Грозине Коростенського району на місті відпрацьованих піщаних кар'єрів. Проектна потужність полігону ТПВ - 2679,570 тис. м³. Полігон площею 30 гектарів діє 3 1972 року. Обсяг накопичення відходів на міському сміттєзвалищі біля с. Грозине Коростенського району представлено в табл. 2.

Таким чином, утворення відходів з року в рік зростає, тоді як значна частка цих відходів видаляється на полігони та сміттєзвалища, які експлуатуються неналежним чином, внаслідок чого створюють негативний вплив на навколишнє природне середовище та здоров’я людей.

Таблиця 2 - Обсяг накопичення відходів на міському сміттєзвалищі, яке розташоване біля с. Грозине Коростенського району

\begin{tabular}{|c|c|c|}
\hline Місяиь & 2016 piк, $\mathrm{M}^{3}$ & 2017 рiк, $M^{3}$ \\
\hline Січень & 5172,745 & 1629,498 \\
\hline Лютий & 5260,078 & 1638,437 \\
\hline Березень & 1866,495 & 2636,213 \\
\hline Квітень & 2180,792 & 2039,533 \\
\hline Травень & 2239,912 & 2572,504 \\
\hline Червень & 2115,332 & 2351,073 \\
\hline Липень & 1841,984 & 2270,092 \\
\hline Серпень & 1900,546 & 2358,2 \\
\hline Вересень & 2075,740 & 2459,6 \\
\hline Жовтень & 1840,328 & 1998,3 \\
\hline Листопад & 1797,448 & 1896,5 \\
\hline Грудень & 1597,688 & 1789,6 \\
\hline
\end{tabular}

Проблеми поводження з ТПВ насамперед стосуються міських територій, але $є$ актуальними для сільської місцевості. У більшості населених пунктів відсутні програми поводження з ТПВ та схеми санітарної очистки населених пунктів, не ведуться реєстри об'єктів утворення, оброблення та утилізації відходів і місць їх видалення, все це призводить до утворення стихійних 
сміттєзвалищ та погіршення санітарного стану населених пунктів. Співвідношення обсягів ТПВ, що утворюються в міській та сільській місцевості складає 63,8 та $36,2 \%$ відповідно.

Якісний аналіз системи управління поводженням 3 відходами Житомирської області дозволив визначити основні проблеми у сфері поводження 3 комунальними відходами та виявити основні причини, які їх викликали. Аналіз таблиць показує, що основною проблемою у сфері поводження з відходами є низька ефективність існуючої системи управління, що супроводжується впровадженням застарілих та низькоефективних методів управління 3 відсутністю ефективної взаємодії всіх учасників процесу поводження $з$ відходами i, в першу чергу, відсутність залучення громади для вирішення проблеми.

Отже, на сьогодні в Житомирі та Житомирській області в сфері управління та поводження з твердими побутовими відходами постали ряд проблем, а саме: збільшилась кількість стихійних сміттєзвалищ (яка 3 кожним роком зростає, хоч комунальні служби і прибирають); недостатня кількість сучасних контейнерів для збору побутових відходів та відсутність контейнерів для роздільного збирання відходів; неналежна якість надання послуг з вивезення твердих побутових відходів; відсутність сміттєпереробного заводу; велика кількість побутових відходів на території міського звалища та відсутність проведення моніторингу його впливу на довкілля.

\section{Висновки}

Таким чином, існуюча структура системи поводження з ТПВ на Житомирщині недосконала, iii фрагментарність, роз'єднаність та різнорідність за відсутності взаємодії 3 органами державного управління, службами охорони навколишнього природного середовища та місцевою громадою не забезпечує достатнього рівня контролю за санітарним станом територій, а також збиранням, транспортуванням, знешкодженням та захороненням комунальних відходів.

Отже, наведені дані свідчать, що за дослідженими показниками Житомирщина ще не забезпечує покращення або хоча б стабільності екологічної безпеки через слабкість економічного механізму впливу на оптимізацію природокористування та захист навколишнього середовища, непослідовне, формальне застосування принципу “забруднювач платить”, вузькість бази екологічного оподаткування, відсутність механізмів індексації нормативної бази тощо.

\section{СПИСОК ЛІТРАТУРИ}

1. Світова статистика у реальному часі: Worldometers [Електронний ресурс]. - Режим доступу: http://www.worldometers.info/uk/

2. Human Development Indices and Indicators: 2018 Statistical Update [Електронний pecypc]. - Режим доступу: https://shop.un.org/books/human-dev-indice-indica-201877373

3. Міністерство регіонального розвитку, будівництва та житлово-комунального господарства [Електронний ресурс]. - Режим доступу: http://www.minregion.gov.ua/ napryamki-diyalnosti/zhkh/terretory/stan-sferi-povodzhennya-z-pobutovimi-vidhodami-vukrayini-za-2018-rik/ 
4. Державний комітет статистики України [Електронний ресурс]. - Режим доступу: http://www.ukrstat.gov.ua/?fbclid=IwAR0FXwk4juzAggg63FmkoaFcFIJ-QFuRcZXyAQV OWE-vLVKko6LTiHpHiVE

5. Класифікація твердих муніципальних відходів - передумова формування ефективної системи поводження $з$ їх потоками / Т. А. Сафранов, Т. П. Шаніна, О. Р. Губанова, В. Ю. Приходько // Вісник Одеського державного екологічного університету. - 2014. - Вип. 18. - С. 32-37.

6. Мандзюк I. А. Питання поводження з промисловими та побутовими відходами / I. А. Мандзюк // Экотехнологии и ресурсосбережение. - 2003. - № 3. - С. 41-43.

7. Управління екобезпекою міста. / І. М. Третьяков [та ін.] ; заг. ред. І. М. Третьяков. К. : Автограф, 2007. - 244 с.

8. Волкова С.А., Пилипчук Л.Л., Ідаятов В.А. Відходи - не забруднювачі довкілля, а не використана вторинна сировина // Мат. Національного форуму «Поводження з відходами в Україні: законодавство, економіка, технології» - К., 2014. - С. 58-61.

9. Коцюба І.Г. Динаміка обсягу накопичення твердих комунальних відходів міста Житомир / Коцюба І.Г., Лико С.М., Лук'янова В.В., Анпілова Є.С. // Екологічна безпека та природокористування. - 2018. - Вип. 1 (25). - С. 33-43.

10. Коцюба І. Г. Прогнозування обсягів утворення твердих побутових відходів в місті Житомирі / І. Г. Коцюба, А. Ф. Щербатюк, Т. Б. Годовська // Вісник національного технічного університету «ХПІ». Серія: механіко-технологічні системи та комплекси Харків, 2016 року. - Вип. №7 - С. 95-100.

11. Anpilova, Y., Lukianova, V., and Trofymchuk, O. (2020). Environmental Safety of Motor Transport Enterprises within Urban Areas. Journal of Ecological Engineering, 21(4), pp. 231-236, https://doi.org/10.12911/22998993/119799

12. Угода про асоціацію України з СС [Електронний ресурс]. - Режим доступу: https://eu-ua.org/tekst-uhody-pro-asotsiatsiiu

13. Офіційний сайт Міністерства екології та природних ресурсів. Принципи реформи управління відходами [Електронний ресурс]. - Режим доступу: https://menr.gov.ua/timeline/Vidhodi-ta-nebezpechni-rechovini.html

14. Національна стратегія управління відходами в Україні до 2030 року [Електронний pecypc]. - Режим доступу: https://zakon3.rada.gov.ua/laws/show/820-2017-\%D1\%80

15. Стручок В., Мудра Д. Аналіз національної стратегії управління відходами в Україні до 2030 року щодо проведення інфраструктурних заходів з перероблення твердих побутових відходів // Матеріали Міжнародної науково-технічної конференції «Фундаментальні та прикладні проблеми сучасних технологій», Тернопіль, 2018. C. 292-293.

16. Методичні рекомендації з розроблення регіональних планів управління відходами [Електронний pecypc]. - Режим доступу: https://menr.gov.ua/files/docs/nakazy/ 2019/nakaz_142.pdf

17. Закон України про Основні засади (стратегію) державної екологічної політики України на період до 2030 року [Електронний ресурс]. - Режим доступу: https://zakon.rada.gov.ua/laws/show/2697-19?fbclid=IwAR0xX2J11QfDh4Ir-87RI8f_Us_ j14_a7kQGuKVZ4D-sPxDM-AYFa_afOs

18. Проект закону України про управління відходами [Електронний ресурс]. - Режим доступу: https://menr.gov.ua/files/images/news_2019/12042019/\%D0\%9F\%D1\%80\% D0\%BE\%D0\%B5\%D0\%BA\%D1\%82_\%D0\%97\%D0\%A3_\%D0\%9F\%D1\%80\%D0\%BE \%D0\%B2i\%D0\%B4\%D1\%85\%D0\%BE\%D0\%B4\%D0\%B8_12.04.2019.doc

19. Реанімаційний пакет реформ. Громадськість закликає Мінприроди прискорити розробку і внести до ВРУ законопроекти про управління відходами [Електронний pecypc]. - Режим доступу: https://rpr.org.ua/news/hromadskist-zaklykaje-minpryrodypryskoryty-rozrobku-i-vnesty-do-vru-zakonoproekty-pro-upravlinnya-vidhodamy/

20. Коцюба І. Г. Прогнозування сезонного морфологічного складу твердих побутових відходів м. Житомира [Текст] / I. Г. Коцюба // Вісник Приазовського державного 
технічного університету: Збірник наукових праць. Серія: Технічні науки. - Маріуполь, 2016. - Вип. 33. - С. 213-222.

21. Лукаш О. В. Несанкціоновані сміттєзвалища Чернігова - осередки поширення інвазійних видів рослин // Мат. Національного форуму «Поводження з відходами в Україні: законодавство, економіка, технології» - К., 2018. - С. 45-46.

22. Podchashinskiy, Y., Kotsiuba, I., Yelnikova, T. (2017). Math modeling and analysis of the impact of municipal solid waste landfill leachate on the environment. Eastern-european journal of enterprise technologies, 1 (10). p. 4-10.

https://doi.org/10.15587/1729-4061.2017.91033

23. Trofymchuk, O., Yakovliev, Y., Klymenko, V., Anpilova, Y. (2019). Geomodeling and monitoring of pollution of waters and soils by the earth remote sensing. In 19th SGEM International Multidisciplinary Scientific GeoConference EXPO Proceedings19th, Science and Technologies in Geology, Exploration And Mining (Vol. 9). STEF92 Technology. https://doi.org/10.5593/sgem2019v/1.4/s02.025

Стаття надійшла до редакиії 18.05 .2020 і прийнята до друку після рещензування 04.09.2020

\section{REFERENCES}

1. Svitova statistika u realnomu chasi [Real-time world statistics]: Worldometers. Retrieved from: http://www.worldometers.info/uk/ (in Ukrainian)

2. Human Development Indices and Indicators: 2018 Statistical Update. Retrieved from: https://shop.un.org/books/human-dev-indice-indica-2018-77373

3. Ministerstvo regionalnogo rozvitku, budivnictva ta zhitlovo-komunalnogo gospodarstva [Ministry for Communities and Territories Development of Ukraine]. Retrieved from: http://www.minregion.gov.ua/napryamki-diyalnosti/zhkh/terretory/stan-sferi-povodzhennyaz-pobutovimi-vidhodami-v-ukrayini-za-2018-rik/ (in Ukrainian)

4. Derzhavnij komitet statistiki Ukrayini [State Statistics Committee of Ukraine]. Retrieved from: http://www.ukrstat.gov.ua/?fbclid=IwAR0FXwk4juzAggg63FmkoaFcFlJ-QFuRcZ XyAQVOWE-vLVKko6LTiHpHiVE (in Ukrainian)

5. Safranov, T. A., Shanina, T. P., Gubanova, O. R., \& Prihodko, V. Yu. (2014). Klasifikaciya tverdih municipalnih vidhodiv - peredumova formuvannya efektivnoyi sistemi povodzhennya z yih potokami [Classification of municipal solid waste is a prerequisite for the formation of an effective system for managing their flows]. Visnik Odeskogo derzhavnogo ekologichnogo universitetu, 18, 32-37. (in Ukrainian)

6. Mandzyuk, I. A. (2003). Pitannya povodzhennya z promislovimi ta pobutovimi vidhodami [Issues of industrial and household waste management]. Ekotehnologii i resursosberezhenie, 3, 41-43. (in Ukrainian)

7. Tretyakov, I.M. et al. (2007). Upravlinnya ekobezpekoyu mista [City eco-safety management]. I.M. Tretyakov (Ed.). Kyiv: Avtograf. (in Ukrainian).

8. Volkova, S.A., Pilipchuk, L.L., \& Idayatov, V.A. (2014). Vidhodi - ne zabrudnyuvachi dovkillya, a ne vikoristana vtorinna sirovina [Waste is not an environmental pollutant, not used secondary raw materials]. Mat. Nacionalnogo forumu «Povodzhennya $z$ vidhodami $v$ Ukrayini: zakonodavstvo, ekonomika, tehnologiyi». (pp. 58-61). Kyiv. (in Ukrainian)

9. Kotsiuba, I., Lyko, S., Lukianova, V., \& Anpilova, Y. (2018). Computational dynamics of municipal wastes generation in Zhytomyr city. Environmental Safety And Natural Resources, 25(1), 33-43. doi:http://dx.doi.org/10.32347/2411-4049.2018.1.33-43

10. Kocyuba, I.G., Sherbatyuk, A.F., \& Godovska, T.B. (2016). Prognozuvannya obsyagiv utvorennya tverdih pobutovih vidhodiv v misti Zhitomiri [Forecasting the volume of solid waste generation in the city of Zhytomyr]. Visnik nacionalnogo tehnichnogo universitetu «HPI». Seriya: mehaniko-tehnologichni sistemi ta kompleksi, 7, 95-100. (in Ukrainian). 
11. Anpilova, Y., Lukianova, V., \& Trofymchuk, O. (2020). Environmental Safety of Motor Transport Enterprises within Urban Areas. Journal of Ecological Engineering, 21(4), 231 236. https://doi.org/10.12911/22998993/119799

12. Ugoda pro asociaciyu Ukrayini z ES [Association Agreement between Ukraine and the EU]. Retrieved from: https://eu-ua.org/tekst-uhody-pro-asotsiatsiiu._(in Ukrainian).

13. Principi reformi upravlinnya vidhodami [Principles of waste management reform]. Oficijnij sajt Ministerstva ekologiyi ta prirodnih resursiv.. Retrieved from: https://menr.gov.ua/timeline/Vidhodi-ta-nebezpechni-rechovini.html_(in Ukrainian)

14. Nacionalna strategiya upravlinnya vidhodami i Ukrayini do 2030 roku [National Waste Management Strategy in Ukraine until 2030]. Retrieved from: https://zakon3.rada.gov.ua/laws/show/820-2017-\%D1\%80_(in Ukrainian).

15. Struchok, V., \& Mudra, D. (2018). Analiz nacionalnoyi strategiyi upravlinnya vidhodami v Ukrayini do 2030 roku shodo provedennya infrastrukturnih zahodiv z pereroblennya tverdih pobutovih vidhodiv [Analysis of the national strategy of waste management in Ukraine until 2030 on the implementation of infrastructure measures for the processing of solid waste]. Mat. Mizhnarodnoyi naukovo-tehnichnoyi konferenciyi «Fundamentalni ta prikladni problemi suchasnih tehnologij». (pp. 292-293). Ternopil. (in Ukrainian).

16. Metodichni rekomendaciyi z rozroblennya regionalnih planiv upravlinnya vidhodami [Methodical recommendations for the development of regional waste management plans]. Retrieved from: https://menr.gov.ua/files/docs/nakazy/2019/nakaz_142.pdf. (in Ukrainian) 17. Zakon Ukrayini pro Osnovni zasadi (strategiyu) derzhavnoyi ekologichnoyi politiki Ukrayini na period do 2030 roku [Law of Ukraine on the Basic Principles (Strategy) of the State Environmental Policy of Ukraine for the period up to 2030]. Retrieved from: https://zakon.rada.gov.ua/laws/show/2697-19?fbclid=IwAR0xX2J11QfDh4Ir-87RI8f_Us_ j14_a7kQGuKVZ4D-sPxDM-AYFa_afOs. (in Ukrainian).

18. Proekt zakonu Ukrayini pro upravlinnya vidhodami [Draft Law of Ukraine on Waste Management]. Retrieved from: https://menr.gov.ua/files/images/news_2019/12042019/\% D0\%9F\%D1\%80\%D0\%BE\%D0\%B5\%D0\%BA\%D1\%82_\%D0\%97\%D0\%A3_\%D0\%9F $\% \mathrm{D} 1 \% 80 \% \mathrm{D} 0 \% \mathrm{BE}$ \%D0\%B2i\%D0\%B4\%D1\%85\%D0\%BE\%D0\%B4\%D0\%B8_12.04.2 019.doc. (in Ukrainian).

19. Reanimacijnij paket reform. Gromadskist zaklikaye Minprirodi priskoriti rozrobku i vnesti do VRU zakonoproekti pro upravlinnya vidhodami [Resuscitation package of reforms. The public calls on the Ministry of Environment to accelerate the development and submit to the Verkhovna Rada bills on waste management]. Retrieved from: https://rpr.org.ua/news/hromadskist-zaklykaje-minpryrody-pryskoryty-rozrobku-i-vnestydo-vru-zakonoproekty-pro-upravlinnya-vidhodamy/. (in Ukrainian).

20. Kocyuba, I.G. (2016). Prognozuvannya sezonnogo morfologichnogo skladu tverdih pobutovih vidhodiv m. Zhitomira. Visnik Priazovskogo derzhavnogo tehnichnogo universitetu: Zbirnik naukovih prac. Seriya: Tehnichni nauki, 33, 213-222. (in Ukrainian)

21. Lukash, O.V. (2018). Nesankcionovani smittyezvalisha Chernigova - oseredki poshirennya invazijnih vidiv roslin [Unauthorized landfills in Chernihiv are centers for the spread of invasive plant species]. Mat. Nacionalnogo forumu «Povodzhennya $z$ vidhodami $v$ Ukrayini: zakonodavstvo, ekonomika, tehnologiyi». (pp. 45-46). Kyiv. (in Ukrainian).

22. Podchashinskiy, Y., Kotsiuba, I., \& Yelnikova, T. (2017). Math modeling and analysis of the impact of municipal solid waste landfill leachate on the environment. Easterneuropean journal of enterprise technologies, 1 (10), 4-10.

https://doi.org/10.15587/1729-4061.2017.91033

23. Trofymchuk, O., Yakovliev, Y., Klymenko, V., \& Anpilova, Y. (2019). Geomodeling and monitoring of pollution of waters and soils by the earth remote sensing. In 19th SGEM International Multidisciplinary Scientific GeoConference EXPO Proceedings19th, Science and Technologies in Geology, Exploration And Mining (Vol. 9). STEF92 Technology. https://doi.org/10.5593/sgem2019v/1.4/s02.025.

The article was received 18.05.2020 and was accepted after revision 04.09.2020 


\section{Коцюба Ірина Григорівна}

завідувач кафедри екології, кандидат технічних наук, доцент Житомирського державного технологічного університету

Адреса робоча: 10005 Україна, м. Житомир, вул. Чуднівська, 103

ORCID: https://orcid.org/0000-0001-6271-7355e-mail: chaszmin30@gmail.com

\section{Лико Сергій Михайлович}

кандидат сільськогосподарських наук, доцент кафедри екології, географії та туризму Рівненського державного гуманітарного університету

Адреса робоча: 33000 Україна, м. Рівне, вул. С. Бандери, 12

ORCID: https://orcid.org/0000-0002-0470-4836e-mail: chaszmin30@gmail.com

\section{Лук'янова Віталіна Віталіївна}

кандидат хімічних наук, доцент кафедри екології та безпеки життєдіяльності Національного транспортного університету

Адреса робоча: 01010, Україна, м. Київ, вул. Омеляновича-Павленка 1, к. 312

ORCID: https://orcid.org/0000-0001-8964-3560e-mail:vitalina_lk@i.ua

\section{Анпілова Свгенія Сергіївна}

кандидат технічних наук, старший науковий співробітник відділу природних ресурсів Інституту телекомунікацій і глобального інформаційного простору НАН України

Адреса робоча: 03186 Україна, м. Київ, Чоколівський бульвар, 13

ORCID: https://orcid.org/0000-0002-4107-0617 e-mail: anpilova@ukr.net 